\title{
Nootropic Effects of $C$. melo and $C$. lanatus seed extracts
}

\author{
Shahana Wahid, ${ }^{1}$ Ali Alqahtani, ${ }^{2}$ and Rafeeq Alam Khan $\mathbb{D}^{1,3}$ \\ ${ }^{1}$ Department of Pharmacology, University of Karachi, Karachi, Pakistan \\ ${ }^{2}$ Department of Pharmacology, College of Pharmacy, King Khalid University, Guraiger, Abha 62529, Saudi Arabia \\ ${ }^{3}$ Faculty of Pharmacy, Ziauddin University, Karachi, Pakistan
}

Correspondence should be addressed to Rafeeq Alam Khan; rkhan1959@gmail.com

Received 16 September 2020; Revised 31 October 2020; Accepted 3 December 2020; Published 10 December 2020

Academic Editor: Kazim Husain

Copyright (C) 2020 Shahana Wahid et al. This is an open access article distributed under the Creative Commons Attribution License, which permits unrestricted use, distribution, and reproduction in any medium, provided the original work is properly cited.

\begin{abstract}
Dementia and related conditions disturb the ability to perform routine life activities prohibiting a person from making appropriate decisions. Seeds of Cucumis melo and Citrullus lanatus have been investigated extensively for various pharmacological properties; hence, considering the presence of bioactive compounds, it was assumed that these seed extracts may support the functioning of the central nervous system. Thus, the present study was designed to investigate the short-term and long-term memory-enhancing effects of $C$. melo and C. lanatus seed extracts in mice by the Morris water maze (spatial learning and memory), stationary rod test, and passive avoidance tests (fear-motivated tests). Ethanol extract of both seeds were prepared by standard procedure and given to animals in the doses of $50 \mathrm{mg} / \mathrm{kg}, 100 \mathrm{mg} / \mathrm{kg}$, and $200 \mathrm{mg} / \mathrm{kg}$. The results were compared to standard drugs diazepam and imipramine given in the doses of $3 \mathrm{mg} / \mathrm{kg}$ and $30 \mathrm{mg} / \mathrm{kg}$, respectively. Extracts of both the seeds were found to possess significant memory and cognition-enhancing effects in mice when tested by passive avoidance, stationary rod, and water maze tests. Results demonstrate memory and cognition-enhancing effects of these extracts which may be due to the presence of bioactive compounds in these seeds.
\end{abstract}

\section{Introduction}

Dementia and related conditions disturb the ability to perform routine life activities prohibiting a person from making appropriate decisions. Learning and memory evaluation is the most tested paradigm which explores the effect of drugs on certain regions of the brain according to the model selected. Learning is the process of attainment of new memories while memory is the recalling of past learned events. It involves encoding, storage, retrieval, and forgetting [1]. Short-term memory is defined as memory over a short time interval while long-term memory refers to the retention of information for a prolonged period of time. Long-term memory is developed due to periodic repetition of information [2]. The normal learning process depends on neurotransmitters like acetylcholine, dopamine, and 5HT which activate the hippocampus (new learning) and amygdala (fear and emotional memories) and other brain areas such as the primary sensory cortex, visual cortex, and auditory cortex [3]. The loss of memory is greatly accelerated by anxiolytics, sedatives, or substances of abuse which result in amnesia. However, cholinesterase inhibitors and dopamine agonists are used to treat dementia [4].

Alzheimer is a neurodegenerative disease with many neuropsychiatric and cognitive problems causing progressive disability and dementia. The condition is either due to the loss of cholinergic neurons especially in the forebrain or reduction in concentration of acetylcholine. The most hopeful treatment for $\mathrm{AD}$ is the use of enzyme acetyl cholinesterase (AChE) inhibitors which mainly produce effects by increasing acetyl choline concentration in the brain. However, drugs which improve memory will have a beneficial effect in Alzheimer's disease (AD). Various plants have been used traditionally for management of many diseases due to the presence of bioactive compounds; thus, extracts from $C$. melo and C. lanatus may lead to discovery of new compounds.

Cucumis melo seeds are a rich source of minerals; vitamins; and enzyme inhibitors like magnesium, potassium, calcium, and sodium [5]; vitamin A; vitamin C; cucurbitacin 
$\mathrm{A}, \mathrm{B}$, and E [6]; $\beta$-carotenes; Apo carotenoids; phosphatidylcholine; melanin; cucumisin; and trypsin inhibitors CMeTI$\mathrm{A}$ and CMeTI-B [7], while various types of glycolipids and free fatty acids are also present like oleic and linolenic acids. Antioxidants such as ellagic acid, gallic acid, and caffeic acid are also present in traces $[8,9]$. Chromone derivatives like beta-sitosterol, beta-amyrin, and beta-sitosterol-3-O-betaglucopyranoside are also present [10].

C. melo has been studied for its antioxidant, gastroprotective, analgesic, anti-inflammatory, antimicrobial, laxative, antigiardial, hepatoprotective, and atherosclerotic properties [11]. There are several studies which show numerous pharmacological properties of $C$. melo seeds like analgesic, antiinflammatory, antioxidant, anticancer, antidiabetic, antiulcer, diuretic and hepatoprotective effects [12]. These effects were thought to be the presence of various phytochemicals [13]. However, no work has been done on CNS effect of $C$. melo seed extract.

C. lanatus is a vitamin C-rich fruit having important phytochemicals and essential amino acids like citrulline, arginine, b-glutamine, and C-aspartic acid [14, 15]. Phytochemicals reported are cucurbitacin E, phenolic compounds, sterols, alkaloids, caprylic acid, capric acid, lauric acid, myristic acid, palmitic acid, stearic acid, oleic acid, linoleic acid, and sterol [16]. Its fruit is utilized for its relaxing and cooling effects.

The seed extract of C. lanatus showed antimicrobial [17], antioxidant, antiulcer [18], and anti-inflammatory activities [19]. The seeds of $C$. lanatus have also found to possess potent analgesic, antitussive, antipyretic, anthelmintic, and immune-modulatory properties, while also having antibacterial, gastroprotective, laxative, antigiardial, and hepatoprotective properties [11]. The seeds can be used for reducing the risk of coronary heart disease and cancer, while also possessing diuretic, antimicrobial, and antifungal activities [19]. Despite all these pharmacological activities, little work has been done to explore the CNS effects of $C$. lanatus.

The loss of memory is not only associated with Alzheimer's but also afflicts individuals under stress. Thus, considering the seriousness of the problem and effectiveness of $C$. melo and C. lanatus seeds in improving overall CNS functions in the peoples of Southeast Asia over years, it was decided, based on previous pharmacological work, to scientifically evaluate memory-enhancing effects of C. melo and C. lanatus $[11,15,16,18,19]$.

\section{Material and Methods}

2.1. Ethical Statement. The study was accompanied following the approval from the Board of Advance Studies and Research, University of Karachi. The reference no. 03297/Pharm was granted by the Board on April 20, 2017, to conduct the study. This approval was followed by the permission of the Departmental Ethical Committee, Department of Pharmacology, for the use of animals as per the National Institutes of Health (NIH) guide for the care and usage of laboratory animals [20].
2.1.1. Preparation of Extract. Seeds of C. melo and C. lanatus were obtained from local medicinal herb sellers, identified by a botanist at the Herbarium, Centre for Plant Conservation, University of Karachi, and deposited as voucher specimen numbers 94494 and 9462, respectively. These seeds after proper washing and drying were milled finely and soaked in $95 \%$ ethanol solution for 21 days. The ratio of soaking was $1 \mathrm{~kg}$ in 1.5 liters. The mixture was agitated several times during the maceration period. The extract was filtered, air dried, freeze dried, and stored in tightly closed bottles at $4^{\circ} \mathrm{C}$ until used. The extraction value of C. melo and C. lanatus was $23.06 \%$ and $17.06 \%$, respectively.

2.2. Experimental Procedures. The extracts of C. melo and C. lanatus were administered daily once a day for 30 days. Behavioral experiments were mainly conducted on days 1 , 8 , and 21.

2.2.1. Passive Avoidance Test. The passive avoidance test is among the quick methods for evaluation of fear aversive memory. The avoidance reaction was determined using an apparatus having light and dark compartments with a grid floor separated by a guillotine door. The black compartment had a grid floor connected to a current supply to give bearable foot shocks. This test was performed in phases of habituation, training, and test sessions. On the $1^{\text {st }}$ and $2^{\text {nd }}$ days of testing, mice were placed in the lighted compartment to habituate for 300 seconds. On the training day, mice were kept in the lighted compartment, facing towards the dark compartment and the guillotine door was opened. When the mice came into the dark compartment, the door was closed and a foot shock $(0.6 \mathrm{~mA}, 0.5 \mathrm{~s}$ duration) was delivered through the grid floor [21]. During the trial, the mice were reintroduced into the apparatus after 3 hours, 24 hours, 8 days, and 21 days to evaluate short-term as well as longterm memory. Mice were placed in the lighted compartment again, and the door was kept open to offer free entry into the dark aversive compartment. The latency to reenter into the dark compartment was noted without applying further current stimulus with a cut-off time of $300 \mathrm{~s}$.

2.2.2. Stationary Rod Test. The learning ability was evaluated by stationary rod test having two elevated stainless steel rods with a fixed netted platform. Initially, mice were trained to learn to walk on the elevated rod by keeping the mice at the center of the stationary rod and pushing towards the platform. Animals were given 4 training trials daily for 4 consecutive days, and a single trial of $120 \mathrm{~s}$. After training, DMSO, standard drug, C. melo, and C. lanatus seed extracts were administered by oral gavage tube for 30 days. Time to reach the platform from the center was noted at day 1 for shortterm learning and at the $8^{\text {th }}$ day and the $21^{\text {st }}$ day for longterm memory [22].

2.2.3. Morris Water Maze Test. The water maze test (MWM) is a commonly recognized method for memory testing. It comprises a rectangular water pool $(60 \times 30 \mathrm{~cm})$ having a fixed central platform $(15 \times 13 \mathrm{~cm})$ filled by starchy tap water maintained at $22-25^{\circ} \mathrm{C}$. During the training period, the platform was visible as the surface of the water was lower, and 
mice were placed in a pool and permitted to remain on the platform for $10 \mathrm{~s}$. Then, the mice were returned to the home cage during the second-trial interval of 120 seconds. The mice that were not able to explore the platform within $120 \mathrm{~s}$ underwent another training session after $10 \mathrm{~s}$ interval [23]. Animals were given 4 training trials daily for 4 consecutive days. DMSO, standard drugs, C. melo, and C. lanatus seed extracts were administered to the mice by oral route after the training trial as per study design, and the mice were tested on the $1^{\text {st }}$ day, $8^{\text {th }}$ day, and $21^{\text {st }}$ day. Decrease in time was taken as memory-recalling process improvement [24-26].

2.2.4. Experimental Animals. Few pairs of albino mice $\mathrm{BALB} / \mathrm{c}$ weighing in the range of $23-29 \mathrm{~g}$ were procured from the Hussain Ebrahim Jamal (HEJ) Research Institute of Chemistry, University of Karachi. Animals were then bred at the animal house, Department of Pharmacology, for use in the study. Young mice, weighing 20-28 g, were housed in a cage at $25^{\circ} \mathrm{C}$ with a controlled alternate $12 \mathrm{~h}$ light and dark cycle having no restriction to food and water. Animals were randomly divided into 9 groups having 10 mice in each group (total 90 animals). The control group received 5\% DMSO; mice in the standard groups received diazepam $3 \mathrm{mg} / \mathrm{kg}$ [27] and imipramine $30 \mathrm{mg} / \mathrm{kg}$ [28]; and mice in the test groups received C. melo and C. lanatus seed extracts at 50, 100 , and $200 \mathrm{mg} / \mathrm{kg}$, respectively, for 30 days. After completion of the study, the mice were sacrificed by decapitation.

2.3. Statistical Methods. Data analysis was performed by oneway ANOVA utilizing SPSS-20 (Superior Performance Statistical Software) and shown as the mean \pm SEM followed by a post hoc Dunnett test to compare values with the control. $P$ value $<0.05$ was considered as significant while $P<0.01$ as highly significant.

\section{Results}

3.1. Passive Avoidance Test. Table 1 shows the effects of ethanol extract of $C$. melo and $C$. lanatus seeds on memory by passive avoidance test. C. melo at $50 \mathrm{mg} / \mathrm{kg}$ and $100 \mathrm{mg} / \mathrm{kg}$ exhibited highly significant increase in latency time to enter the dark chamber at $3 \mathrm{~h}, 24 \mathrm{~h}, 8^{\text {th }}$ day, and $21^{\text {st }}$ day while $C$. melo at $200 \mathrm{mg} / \mathrm{kg}$ exhibited highly significant increase in latency time up to the $8^{\text {th }}$ day. C. lanatus at $50 \mathrm{mg} / \mathrm{kg}$ exhibited significant increase in latency time to enter the dark chamber at $3 \mathrm{~h}$ and highly significant increase in latency time at $24 \mathrm{~h}$ and $8^{\text {th }}$ day. C. lanatus at $100 \mathrm{mg} / \mathrm{kg}$ showed highly significant increase in latency time to enter the dark chamber at $3 \mathrm{~h}, 24 \mathrm{~h}, 8^{\text {th }}$ day, and $21^{\text {st }}$ day as compare to the control, while the C. lanatus at $200 \mathrm{mg} / \mathrm{kg}$ group showed significant increase in latency time to enter the dark chamber at $3 \mathrm{~h}$ and highly significant increase in latency time at $24 \mathrm{~h}$ and $21^{\text {st }}$ day. Latency time to enter in dark compartment was found significantly shorter in mice receiving standard drug diazepam $3 \mathrm{mg} / \mathrm{kg}$ on the 8 th and 21st days, while in the case of mice receiving imipramine $30 \mathrm{mg} / \mathrm{kg}$, latency time to enter the dark compartment was found significantly longer at $3 \mathrm{~h}$, $24 \mathrm{~h}, 8^{\text {th }}$ day, and $21^{\text {st }}$ day as compared to the control.
3.2. Stationary Rod Test. Table 2 shows effects of ethanol extract of $C$. melo and C. lanatus seeds on memory by stationary rod test. $C$. melo seed extracts at $50 \mathrm{mg} / \mathrm{kg}$ and $100 \mathrm{mg} / \mathrm{kg}$ exhibited highly significant decrease in time to reach elevated platform at $24 \mathrm{~h}, 8^{\text {th }}$ day, and $21^{\text {st }}$ day as compared to the control.

C. lanatus at $50 \mathrm{mg} / \mathrm{kg}$ and $100 \mathrm{mg} / \mathrm{kg}$ exhibited highly significant decrease in the time to reach the platform at $24 \mathrm{~h}, 8^{\text {th }}$ day, and $21^{\text {st }}$ day as compared to the control, while C. lanatus at $200 \mathrm{mg} / \mathrm{kg}$ showed significant increase in the latency time at $24 \mathrm{~h}$ and a highly significant decrease in the time to reach the platform at the $8^{\text {th }}$ and $21^{\text {st }}$ days as compared to the control.

3.3. Water Maze Test. Table 3 shows the memory-enhancing effects of $C$. melo and C. lanatus seed extracts in the water maze test. Shorter time to reach the hidden platform was considered as the index of retrieval of memory. C. melo at $50 \mathrm{mg} / \mathrm{kg}$ exhibited highly significant decrease in time to reach the platform at $24 \mathrm{~h}, 8^{\text {th }}$ day, and $21^{\text {st }}$ day as compared to the control. C. melo at $100 \mathrm{mg} / \mathrm{kg}$ exhibited a significant shorter time to reach the platform at $24 \mathrm{~h}$, while it showed a highly significant decrease in time to reach the platform at the $8^{\text {th }}$ and $21^{\text {st }}$ days as compared to the control. C. melo at $200 \mathrm{mg} / \mathrm{kg}$ showed significant decrease in the time to reach the platform at $24 \mathrm{~h}$ and a highly significant decrease in the time to reach the platform on the $8^{\mathrm{th}}$ day.

C. lanatus at $50 \mathrm{mg} / \mathrm{kg}$ and $100 \mathrm{mg} / \mathrm{kg}$ exhibited a highly significant decrease in the time to reach the platform on the $8^{\text {th }}$ day and significant decrease in the time to reach the platform on the $21^{\text {st }}$ day as compared to the control. C. lanatus at $200 \mathrm{mg} / \mathrm{kg}$ exhibited a highly significant decrease in the time to reach the platform at $24 \mathrm{~h}$ and the $8^{\text {th }}$ day while exhibiting significant decrease in time to reach the platform on the $21^{\mathrm{st}}$ day as compared to the control.

Animals given standard drug diazepam $3 \mathrm{mg} / \mathrm{kg}$ showed highly significant increase in the time to reach the platform on the $8^{\text {th }}$ and $21^{\text {st }}$ days while imipramine $30 \mathrm{mg} / \mathrm{kg}$ showed highly significant decrease in the time to reach the platform on the $8^{\mathrm{th}}$ and $21^{\text {st }}$ days as compared to the control.

\section{Discussion}

Dementia is a condition which is either produced due to the use of drugs like anxiolytics, sedatives, or neurodegenerative disorders like Parkinson's and Alzheimer or aging [4]. According to Ahmed and coworkers [29], worldwide, 24.3 million people are suffering from dementia with the increment of 4.6 million cases every year making it a major contributor of normal life disability. This emphasizes the need of newer drugs which can improve the memory without adverse effects. Hence, the current study was designed to explore nootropic effects of edible seeds using three different models i.e., the water maze, stationary rod, and passive avoidance tests. In all three models, seed extracts at $50 \mathrm{mg} / \mathrm{kg}$ and $100 \mathrm{mg} / \mathrm{kg}$ showed memory-enhancing effects as indicated by a significant increase in latency time both at shortand long-term levels as compared to the control. However, 
TABle 1: Effects of C. melo and C. lanatus seed extracts on memory (passive avoidance).

\begin{tabular}{|c|c|c|c|c|}
\hline \multirow{2}{*}{ Groups \& doses (mg/kg) } & \multicolumn{4}{|c|}{ Latency time (sec) } \\
\hline & $3 \mathrm{~h}$ & $24 \mathrm{~h}$ & $8^{\text {th }}$ day & $21^{\text {st }}$ day \\
\hline Control & $115 \pm 34$ & $99 \pm 11.6$ & $94 \pm 15$ & $55 \pm 6.26$ \\
\hline C. melo 50 & $274 \pm 26^{* *}$ & $300 \pm .0 .0^{* *}$ & $271 \pm 29.1^{* *}$ & $261 \pm 28^{* *}$ \\
\hline C. melo 100 & $272 \pm 28^{* *}$ & $258 \pm 29^{* *}$ & $242 \pm 29.7^{* *}$ & $246 \pm 28^{* *}$ \\
\hline C. melo 200 & $266 \pm 28^{* *}$ & $289 \pm 10.5^{* *}$ & $259 \pm 27.3^{* *}$ & $111 \pm 27$ \\
\hline C. lanatus 50 & $236 \pm 32^{*}$ & $281 \pm 18.5^{* *}$ & $285 \pm 15.2^{* *}$ & $104 \pm 33$ \\
\hline C. lanatus 100 & $300 \pm 0.0^{* *}$ & $300 \pm 0.0^{* *}$ & $271 \pm 29^{* *}$ & $222 \pm 26^{* *}$ \\
\hline C. lanatus 200 & $226 \pm 36^{*}$ & $260 \pm 26.7^{* *}$ & $168.65 \pm 36$ & $237 \pm 28.5^{* *}$ \\
\hline Diazepam 3 & $155 \pm 65$ & $86 \pm 13.5$ & $16 \pm 3.1^{*}$ & $32 \pm 14^{*}$ \\
\hline Imipramine 30 & $257 \pm 43^{*}$ & $245 \pm 54.6^{*}$ & $269 \pm 31^{*}$ & $209 \pm 39^{*}$ \\
\hline
\end{tabular}

$n=10$. Mean \pm SEM. ${ }^{*} P<0.05$ significant as compared to the control; ${ }^{* *} P<0.01$ highly significant as compared to the control.

TABLE 2: Effects of C. melo and C. lanatus seed extracts on memory by stationary rod.

\begin{tabular}{|c|c|c|c|c|}
\hline \multirow{2}{*}{ Groups \& doses $(\mathrm{mg} / \mathrm{kg})$} & \multicolumn{4}{|c|}{ Time to reach platform (sec) } \\
\hline & Learning & $24 \mathrm{~h}$ & $8^{\text {th }}$ day & $21^{\text {st }}$ day \\
\hline Control & $12.04 \pm 1.0$ & $19.5 \pm 1.1$ & $25.9 \pm 0.8$ & $26.3 \pm 1.1$ \\
\hline C. melo 50 & $11.9 \pm 0.8$ & $7.6 \pm 0.9^{* *}$ & $5.3 \pm 0.3^{* *}$ & $9.9 \pm 1.3^{* *}$ \\
\hline C. melo 100 & $14 \pm 1.1$ & $6.7 \pm 0.4^{* *}$ & $8.0 \pm 0.7^{* *}$ & $10.0 \pm 1.0^{* *}$ \\
\hline C. melo 200 & $18 \pm 1.1$ & $14.8 \pm 1.5$ & $12.5 \pm 1$ & $15.1 \pm 1.2$ \\
\hline C. lanatus 50 & $16.5 \pm 1.3$ & $6.6 \pm 0.5^{* *}$ & $7 \pm 0.6^{* *}$ & $8.8 \pm 1.4^{* *}$ \\
\hline C. lanatus 100 & $12.7 \pm 0.5$ & $8.8 \pm 0.9^{* *}$ & $8.3 \pm 1^{* *}$ & $8.7 \pm 1.1^{* *}$ \\
\hline C. lanatus 200 & $14.5 \pm 1.5$ & $11.1 \pm 0.7^{*}$ & $11.6 \pm 0.6^{* *}$ & $9 \pm 1.0^{* *}$ \\
\hline Diazepam 3 & $16.3 \pm 0.6$ & $28 \pm 5$ & $63.4 \pm 8.5^{* *}$ & $82.9 \pm 10.5^{* *}$ \\
\hline Imipramine 30 & $13.9 \pm 1.6$ & $11.9 \pm 1.8$ & $8.2 \pm 1.5^{* *}$ & $6.2 \pm 0.9^{* *}$ \\
\hline
\end{tabular}

$n=10$. Mean \pm SEM. ${ }^{*} P<0.05$ significant as compared to the control; ${ }^{* *} P<0.01$ highly significant as compared to the control.

TABLE 3: Effects of C. melo and C. lanatus seed extracts on memory by water maze test.

\begin{tabular}{|c|c|c|c|c|}
\hline \multirow{2}{*}{ Groups \& doses (mg/kg) } & \multicolumn{4}{|c|}{ Time to reach platform $(\mathrm{sec})$} \\
\hline & Learning & $24 \mathrm{~h}$ & $8^{\text {th }}$ day & $21^{\text {st }}$ day \\
\hline Control & $14.4 \pm 1.5$ & $10.3 \pm 0.7$ & $19.0 \pm 0.9$ & $20.3 \pm 0.7$ \\
\hline C. melo 50 & $15.5 \pm 1.5$ & $3.4 \pm 0.5^{* *}$ & $3.9 \pm 0.5^{* *}$ & $5.6 \pm 0.6^{*}$ \\
\hline C. melo 100 & $13.9 \pm 1.8$ & $4.7 \pm 0.7^{*}$ & $3.3 \pm 0.6^{* *}$ & $6.4 \pm 1^{*}$ \\
\hline C. melo 200 & $16.3 \pm 1.1$ & $5.0 \pm 0.9^{*}$ & $6.4 \pm 1.0^{* *}$ & $25.9 \pm 3.9$ \\
\hline C. lanatus 50 & $9.6 \pm 2$ & $5.4 \pm 1.04$ & $4.6 \pm 0.3^{* *}$ & $4.4 \pm 0.7^{*}$ \\
\hline C. lanatus 100 & $7.8 \pm 1.4$ & $5.3 \pm 0.5$ & $2.6 \pm 0.30^{* *}$ & $3.9 \pm 0.6^{*}$ \\
\hline C. lanatus 200 & $8.0 \pm 2$ & $3.6 \pm 0.3^{* *}$ & $3.5 \pm 0.3^{* *}$ & $5.6 \pm 0.7^{*}$ \\
\hline Diazepam 3 & $15.2 \pm 0.8$ & $33.8 \pm 2.7^{* *}$ & $36.6 \pm 2.9^{* *}$ & $91.7 \pm 13.1^{* *}$ \\
\hline Imipramine 30 & $13.9 \pm 1.6$ & $11.9 \pm 1.8$ & $8.2 \pm 1.5^{* *}$ & $6.2 \pm 0.9^{* *}$ \\
\hline
\end{tabular}

$n=10$. Mean \pm SEM. ${ }^{*} P<0.05$ significant as compared to the control; ${ }^{* *} P<0.01$ highly significant difference as compared to the control.

at the $200 \mathrm{mg} / \mathrm{kg}$ dose, the effects were similar to the control due to increase in passivity.

In the present study, nootropic effects of $C$. melo and $C$. lanatus were evaluated using three different models of memory, i.e., passive avoidance, stationary rod, and water maze tests. Seed extracts of C. melo and C. lanatus showed an increment in the memory-recalling process for short- and longterm memory as compared to the control and standard in all three models at doses of 50 and $100 \mathrm{mg} / \mathrm{kg}$; hence, it may be suggested that both seeds have cognition enhancement ability. 
However, at $200 \mathrm{mg} / \mathrm{kg}$ doses, effects were similar to the control due to the increment in passivity.

There are several drugs which at high doses may activate sedative activity and passivity just like diazepam. In the treatment of moderate anxiety, the initially selected human dose is $2 \mathrm{mg}$ thrice a day which can be increased depending upon the required anxiolytic effects, while for sleep problems, the starting dose is $5 \mathrm{mg}$ which is almost twice that of the anxiolytic dose which can be increased up to $15 \mathrm{mg}$.

Memory-enhancing effects of $C$. melo and C. lanatus may be due to the presence of cucurbitacin B and cucurbitacin E, since these cucurbitacins are thought to produce neurogenesis and neuroprotective effects $[30,31]$. The bioactive compounds in $C$. melo are thought to inhibit $\beta$-secretase responsible for producing $\beta$-amyloid [32], which is a toxic protein, causing neuronal loss in selected brain areas, hence producing memory-enhancing effects. Sang-Shin and coworkers reported memory-enhancing effects of the C. melo extract at the dose of $100 \mathrm{mg} / \mathrm{kg}$ due to inhibition of acetyl cholinesterase; thus, results of the present study are in accordance with previous studies.

Seeds of $C$. melo contain ketogenic amines like tryptophan and lysine [33] which improve cognitive functions. Thaipisuttikul and Galvin [34] reported that C. lanatus contains caprylic acid which is thought to bypass the metabolic impairment of energy as identified in AD. Hence, various dietary patterns containing a ketogenic diet are suggested to reduce the neuropathological complications [35]. Furthermore, C. lanatus contains L-citrulline which is a precursor of arginine [36]. Citrulline has been supposed to increase energy levels, stimulate immune system, and detoxify ammonia [37].

Citrulline due to its potent hydroxyl free radical scavenging activity acts as an immunomodulator and is supposed to be beneficial in various conditions including multi-infarct dementia. It also enhances NO production and in turn suppresses the risk of myocardial oxidative stress. Hence, these seeds may be effective for prevention and treatment of oxidative stress-induced cardiovascular disease [38].

Evidence suggests that $\mathrm{NO}$ also have a role in learning and memory on activation of N-methyl-D-aspartate (NMDA) receptors [39]. NMDA receptors in the brain have been shown to play a vital role in several types of learning [40]. Studies in animals also revealed that blockade of NO synthesis in vivo impairs learning behavior [41]. Moreover, L-arginine has been found to decrease lipid peroxidation and improve cognitive function in elderly patients with dementia [42]. Further $\mathrm{Yi}$ et al. [43] revealed that Larginine improves loss of memory due to its effects on neurogenesis.

The findings of the current study are quite significant since they imply memory-enhancing effects on the symptoms of $\mathrm{AD}$, which is a chronic progressive brain disease associated with loss of memory and diminished intellectual capabilities due to degeneration of neurons.

\section{Conclusion}

The study has put forward significant findings regarding CNS-related benefits of C. melo and C. lanatus, since extracts of these seeds have been effective in improving memory and cognition. It implies that such properties may have a role in reducing amnesia. Moreover, being a dietary component can be used safely in elderly patients to reduce the symptoms of Alzheimer disease and amnesia.

\section{Data Availability}

The data generated or analyzed in the study is included in this article; its supplementary information is available with the first author which can be made available on request.

\section{Consent}

I, Shahana Wahid, and Ali Alqahtani have given our consent for the publication of the manuscript "Nootropics Effects of C. melo and C. lanatus Seed Extracts" to the corresponding author Rafeeq Alam Khan in BioMed Research International.

\section{Conflicts of Interest}

The authors declare that they have no competing interests.

\section{Acknowledgments}

The authors are thankful to the Department of Pharmacology, University of Karachi for the assistance provided to complete this study. Financial support has been provided by the Department of Pharmacology, University of Karachi.

\section{References}

[1] H. Okano, T. Hirano, and E. Balaban, "Learning and memory," Proceedings of the National Academy of Sciences, vol. 97, no. 23, pp. 12403-12404, 2000.

[2] T. A. H. Katus and S. K. Andersen, "The role of spatial attention in tactile short-term memory," in Mechanisms of Sensory Working Memory: Attention and Performance XXV, P. Jolicoeur, C. Lefebvre, and J. Martinez-Trujillo, Eds., pp. 275292, Elsevier, 2015.

[3] B. Wiltgen, M. Sanders, S. Anagnostaras, J. Sage, and M. Fanselow, "Context fear learning in absence of the hippocampus," J. Neurosci, vol. 26, pp. 5484-5491, 2006.

[4] C. O'Luanaigh and B. Lawlor, "Drugs that affect competence," in Competence Assessment in Dementia, Springer-Verlag/Wien, 2008.

[5] N. Bouazzaoui, W. Drici, W. Bouazzaoui et al., "Fatty acids and mineral composition of melon (Cucumis melo L. Inodorus) seeds from West Algeria," Mediterranean Journal of Chemistry, vol. 5, no. 1, pp. 340-346, 2016.

[6] J. C. Chen, M. H. Chiu, R. L. Nie, G. A. Cordell, and S. X. Qiu, "Cucurbitacins and cucurbitane glycosides: structures and biological activities," Natural Product Reports, vol. 22, no. 3, pp. 386-399, 2005.

[7] K. C. Huang, The Pharmacology of Chinese Herbs, CRC Press, Boca Raton, London, New York, 1999.

[8] C. C. Peng, C. L. Hsieh, H. E. Wang, J. Y. Chung, and K. C. Chen, "Ferulic acid is nephrodamaging while gallic acid is renal protective in long term treatment of chronic kidney disease," Clinical Nutrition, vol. 31, no. 3, pp. 405-414, 2012. 
[9] F. M. Vella, D. Cautela, and B. Laratta, "Characterization of polyphenolic compounds in cantaloupe melon by-products," vol. 8, no. 6, p. 196, 2019.

[10] D. S. Ibrahim, "Neuroprotective effect of Cucumis melo Var. flexuosus leaf extract on the brains of rats with streptozotocin-induced diabetes," Metabolic Brain Disease, vol. 32, pp. 69-75, 2016.

[11] C. D. Deshmukh, A. Jain, and M. S. Tambe, "Phytochemical and pharmacological profile of Citrullus lanatus (THUNB)," Biolife, vol. 3, pp. 483-488, 2015.

[12] M. Waseem, A. Rauf, S. Rehman, and R. Ahmed, "Pharmacognostical and pharmacological review of Cucumis Melo L. including Unani medicine perspective," International Journal of Pharmacognosy \& Chinese Medicine, vol. 2, no. 3, article 000140, 2018.

[13] C. Chen, S. Qiang, L. Lou, and W. Zhao, "Cucurbitane-type triterpenoids from the stems of Cucumis melo," Journal of Natural Products, vol. 72, no. 5, pp. 824-829, 2009.

[14] A. Adetutu, O. S. Olorunnisola, and O. A. Owoade, "Nutritive values and antioxidant activity of Citrullus lanatus fruit extract," Food and Nutrition Sciences, vol. 6, no. 11, pp. 1056-1064, 2015.

[15] R. Ridwan, H. R. Abdul Razak, M. I. Adenan, and M. S. Wan Mazlina, "Development of isocratic RP-HPLC method for separation and quantification of L-citrulline and L-arginine in watermelons," International Journal of Analytical Chemistry, vol. 2018, Article ID 4798530, 8 pages, 2018.

[16] L. Okunrobo, U. O. John, I. E. Kate, O. Osarumwense, and O. E. Jude, "Quantitative determination, metal analysis and antiulcer evaluation of methanol seeds extract of Citrullus lanatus Thunb (Cucurbitaceae) in rats," Asian Pacific Journal of Tropical Biomedicine, vol. 2, pp. S1261-S1265, 2012.

[17] H. S. Bello, H. Y. Ismail, M. H. Goje, and H. Mangga, "Antimicrobial activity of Citrullus lanatus (watermelon) seeds on some selected bacteria," Journal of Biotechnology Research, vol. 2, pp. 39-43, 2016

[18] S. I. Abdelwahab, A. H. Loiy Elsir, H. M. Sirat et al., "Antiinflammatory activities of cucurbitacin $\mathrm{E}$ isolated from Citrullus lanatus var. citroides: role of reactive nitrogen species and cyclooxygenase enzyme inhibition," Fitoterapia, vol. 82, no. 8, pp. 1190-1197, 2011.

[19] L. E. Ahmed, H. M. Sirat, S. Yagi, W. S. Koko, and S. Abdelwahab, "In-vitro antimicrobial activities of chloroformic, hexane and ethanol extracts of Citrullus lanatus var. citroides," Journal of Medicinal Plants Research, vol. 5, pp. 1338-1344, 2011.

[20] National Research Council, "Guide for the care and use of laboratory animals," the National Academic Press, Washington, DC, USA, 8th edition, 2011

[21] J. Cho, J. S. Kang, P. H. Long, J. Jing, Y. Back, and K. S. Chung, "Antioxidant and memory enhancing effects of purple sweet potato anthocyanin and cordyceps mushroom extract," Archives of Pharmacal Research, vol. 26, no. 10, pp. 821-825, 2003.

[22] A. Kishioka, F. Fukushima, T. Ito et al., "A novel form of memory for auditory fear conditioning at a low-intensity unconditioned stimulus," PLoS One, vol. 4, no. 1, article e4157, 2009.

[23] R. D'Hooge and P. P. De Deyn, "Applications of the Morris water maze in the study of learning and memory," Brain Research. Brain Research Reviews, vol. 36, no. 1, pp. 60-90, 2001.
[24] L. M. Gallivan and N. Schmitzer-Torbert, "A low-cost Morris water maze for undergraduate research: construction and demonstration in a rat model of obesity-induced diabetes," Journal of Undergraduate Neuroscience Education, vol. 16, pp. A143-A151, 2018.

[25] R. G. M. Morris, "Spatial localization does not require the presence of local cues," Learning and Motivation, vol. 12, no. 2, pp. 239-260, 1981.

[26] E. Russo, S. Chimirri, R. Aiello et al., "Lamotrigine positively affects the development of psychiatric comorbidity in epileptic animals, while psychiatric comorbidity aggravates seizures," Epilepsy \& Behavior, vol. 28, no. 2, pp. 232-240, 2013.

[27] L. Cheng, G. Pan, X. Sun, Y. Huang, Y. Peng, and L. Zhou, "Evaluation of anxiolytic-like effect of aqueous extract of asparagus stem in mice," Evidence-Based Complementary and Alternative Medicine, vol. 2013, Article ID 587260, 10 pages, 2013.

[28] M. Podolan, J. D. Santos, T. Walber, F. Possamai, G. G. Viola, and O. C. Linode, "A single injection of imipramine affected proliferation in the hippocampus of adult Swiss mice depending on the route of administration, doses, survival time and lodging conditions," Journal of Chemical Neuroanatomy, vol. 100, article 101655, 2019.

[29] A. Ahmad, K. Owais, M. Siddiqui, K. Mamun, and F. Rao, "Dementia in Pakistan: national guidelines for clinicians," Pakistan Journal of Neurological Sciences, vol. 8, p. 7, 2013.

[30] A. M. Arel-Dubeau, F. Longpré, J. Bournival et al., "Cucurbitacin $\mathrm{E}$ has neuroprotective properties and autophagic modulating activities on dopaminergic neurons," Oxidative Medicine and Cellular Longevity, vol. 2014, Article ID 425496, 15 pages, 2014.

[31] J. Li, K. Sun, M. Muroi et al., "Cucurbitacin B induces neurogenesis in PC12 cells and protects memory in APP/PS1 mice," Journal of Cellular and Molecular Medicine, vol. 23, no. 9, pp. 6283-6294, 2019.

[32] P. Sang-Shin, P. Na-Omi, K. Ju-Uk, S. Suk-Chul, and L. DongUng, "Cognition enhancing effect of muskmelon (Cucumis melo) extracts on scopolamine-induced memory impairment in mice," Journal of Life Science, vol. 19, pp. 688-691, 2009.

[33] S. Mallek-Ayadi, N. Bahloul, and N. Kechaou, "Phytochemical profile, nutraceutical potential and functional properties of Cucumis melo L. seeds," Journal of Science and Food Agriculture, vol. 99, pp. 1294-1301, 2019.

[34] P. Thaipisuttikul and J. E. Galvin, "Use of medical foods and nutritional approaches in the treatment of Alzheimer's disease," Clinical Practice, vol. 9, no. 2, pp. 199-209, 2012.

[35] M. Rusek, R. Pluta, M. Ułamek-Kozioł, and S. J. Czuczwa, "Ketogenic diet in Alzheimer's disease," International Journal of Molecular Sciences, vol. 20, no. 16, article 3892, 2019.

[36] J. K. Collins, G. Wu, P. Perkins-Veazie et al., "Watermelon consumption increases plasma arginine concentrations in adults," Nutrition, vol. 23, no. 3, pp. 261-266, 2007.

[37] P. A. Balch, Prescription for nutritional healing. The $A$ to $Z$ guide to supplements, Avery a member of Penguin Putnam Inc., 375 Hudson street, New York, 10014, USA, 2nd edition, 2002.

[38] A. Laurentius, G. B. Wikanendra, T. H. Cong, and W. Arozal, "L-citrulline as alternative pharmacological substance in protecting against cardiovascular disease," Pharmaceutical Sciences and Research, vol. 5, pp. 72-80, 2018.

[39] G. A. Bohme, C. Bon, J. M. Stutzmann, A. Doble, and J. C. Blanchard, "Possible involvement of nitric oxide in long- 
term potentiation," European Journal of Pharmacology, vol. 199, pp. 379-381, 1991.

[40] A. H. Rezvani, "Involvement of the NMDA system in learning and memory," in Animal Models of Cognitive Impairment, L. Ed and J. J. Buccafusco, Eds., CRC Press/Taylor \& Francis, Boca Raton, FL, USA, 2006.

[41] P. F. Chapman, C. M. Atkins, M. T. Allen, J. E. Haley, and J. E. Steinmetz, "Inhibition of nitric oxide synthesis impairs two different forms of learning," Neuroreport, vol. 3, no. 7, pp. 567-570, 1992.

[42] Y. Ohtsuka, "Effect of oral administration of L-arginine on senile dementia," The American Journal of Medicine, vol. 108, p. 439, 2000.

[43] J. Yi, L. L. Horky, A. L. Friedlich, Y. Shi, J. T. Rogers, and $\mathrm{X}$. Huang, "L-Arginine and Alzheimer's disease," International Journal of Clinical and Experimental Pathology, vol. 2, no. 3, pp. 211-238, 2009. 